OPEN ACCESS

Edited by:

Colin McCarter

University of Toronto

Scarborough, Canada

Reviewed by:

Sébastien Gogo,

University of Orléans, France

Bijendra Man Bajracharya,

University of Waterloo, Canada

*Correspondence:

Chris Freeman

c.freeman@bangor.ac.uk

Line Rochefort

Line.Rochefort@fsaa.ulaval.ca

Specialty section:

This article was submitted to

Biogeochemical Dynamics,

a section of the journal

Frontiers in Environmental Science

Received: 22 May 2019

Accepted: 08 April 2020

Published: 12 May 2020

Citation:

Alshehri A, Dunn C, Freeman C,

Hugron S, Jones TG and Rochefort L

(2020) A Potential Approach for

Enhancing Carbon Sequestration

During Peatland Restoration Using

Low-Cost, Phenolic-Rich Biomass

Supplements.

Front. Environ. Sci. 8:48.

doi: 10.3389/fenvs.2020.00048

\section{A Potential Approach for Enhancing Carbon Sequestration During Peatland Restoration Using Low-Cost, Phenolic-Rich Biomass Supplements}

\author{
Adel Alshehri ${ }^{1}$, Christian Dunn ${ }^{1}$, Chris Freeman ${ }^{1 *}$, Sandrine Hugron ${ }^{2}$, Timothy G. Jones ${ }^{1}$ \\ and Line Rochefort ${ }^{2 *}$ \\ ${ }^{1}$ Bangor Wetlands Group, Wolfson Carbon Capture Laboratories, School of Natural Science, Brambell Building, Bangor \\ University, Bangor, United Kingdom, ${ }^{2}$ Peatland Ecology Research Group (PERG), Centre for Northern Studies (CEN), \\ Université Laval, Quebec City, QC, Canada
}

The addition of phenolic compounds to peatland soils has been proposed as a means of enhancing the suppression of enzymes, reducing the rate of organic matter decomposition and increasing below-ground carbon sequestration. This study evaluated the potential of phenolic enrichment as a peatland restoration strategy by adding wood chips from common tree species to peat substrate and determining the impacts on key components of organic matter decomposition and Sphagnum growth. All treatments tended to increase the concentration of phenolics and suppress the activities of $\beta$-glucosidase (measured as an indicator enzyme that plays a key role in cellulose decomposition), significantly so with the Spruce (Picea mariana) and Cedar (Thuja occidentalis) wood chips mixed into the peat. All substrate additions to the peat tended to reduce fluxes of carbon dioxide $\left(\mathrm{CO}_{2}\right)$ and significantly more so with surface additions of Spruce and Larch (Larix laricina) wood chips. The addition of woodchips per se had no detrimental effect on Sphagnum growth for any of the treatments. These results indicate that through the addition of phenolic compounds to peatlands, it may be possible to inhibit extracellular enzyme activities in order to reduce the flux of $\mathrm{CO}_{2}$ from soils to the atmosphere. Thus, organic soil conditioning could reduce the carbon footprint for commercial activities such as Sphagnum culture.

Keywords: peatlands, phenolics, hydrolase enzymes, carbon dioxide, Sphagnum culture, geoengineering

\section{INTRODUCTION}

Peatland ecosystems are freshwater wetlands that accumulate partially decomposed organic material derived from decaying plant matter. Globally, peatlands cover $2.84 \%$ of the land surface, but the amount of carbon stored as peat is equivalent to $20 \%$ of the world's soil carbon and $60 \%$ of the carbon currently in the atmosphere (Joosten, 2016; Xu et al., 2018). Peat forms where the water table is close to the ground surface, creating anaerobic conditions in the soil that are unfavorable 
for complete decomposition of plant matter. According to the enzymic latch theory (Freeman et al., 2001), the lack of oxygen prevents the enzyme phenol oxidase from breaking down phenolic compounds, which are released into the soil following plant senescence (Northup et al., 1998; Meier et al., 2008). These compounds are inhibitory to hydrolase enzymes (Freeman et al., 1990; Wetzel, 1992; Tejirian and Xu, 2011), the main agents of decomposition in soils; therefore, their suppressed activity causes organic matter to accumulate.

Large areas of peatlands have been disturbed by drainage and land use conversion for urbanization, forestry, agriculture, and peat extraction (Joosten et al., 2016). The lowered water table in degraded peatlands can allow oxygen ingress "opening" the enzymic latch causing these wetlands to lose their ability to sequester carbon and potentially to become net sources of carbon by oxidation of accumulated peat, having important repercussions for climate change (Paul and Clark, 1989; Laine and Minkkinen, 1996; Waddington et al., 2002; Ramchunder et al., 2009). In extreme dry conditions (particularly in aged Sphagnum peat), constraints on decomposing communities from poor water availability can become more important than oxygen constraints (Toberman et al., 2008), however leading structural changes in Sphagnum communities to potentially become the dominant determinant of decomposition.

Poikilohydric Sphagnum plants can maintain waterlogging in surface peat and their tissues also contain an oxopolysaccharide (Painter, 1983) and phenolic compounds (Rasmussen et al., 1995) that suppress soil heterotroph and extracellular enzyme activity (Verhoeven and Toth, 1995; Freeman et al., 2001), thereby impeding decomposition, although the importance of Sphagnum solely derived soluble phenolics are being questioned compared to vascular-plant-derived phenolics. Similarly, microorganisms can be manipulated in peatlands by adding inhibitory phenolics, such as is present in woody plants, which have the potential to reduce the rate of decomposition of soil organic matter (SOM) (Freeman et al., 2012; Fenner and Freeman, 2020) by strengthening the enzymic latch mechanism (Freeman et al., 2001). Woody plants are principle producers of polyphenols (Haslam, 1989). Lignin, a complex polyphenol, can ensure long-term recalcitrance in litter and therefore exert control over fine scale decomposition dynamics (Horner et al., 1988).

In this study, we investigated a new approach for potentially enhancing below-ground carbon storage in restored peatlandsthe use of phenolic (i.e., vascular-plant-derived lignin) enrichment as a strategy for strengthening the "enzymic latch mechanism" that exerts a strong influence on controls of the rate of decomposition in peatland soils. For example, this can be achieved by (a) strengthening the enzymic latch by either increasing the abundance of phenolic inhibitors or (b) by increasing the amount of $\mathrm{C}$ influenced by the enzymic latch (Freeman et al., 2012). In this study, wood chip fragments from three tree species have been selected to test as phenolic inhibitors to promote $\mathrm{C}$ sequestration in the peat soil while also determining the impact on Sphagnum growth, according to these hypotheses:
- The addition of coniferous wood chips to peat soil will increase the concentration of polyphenolic compounds. The coniferous wood chips selected represent the three most common trees present in peatlands of North America and are thus a low cost source of phenolics.

- The increase in phenolic compounds will lead to lower hydrolase enzyme activities and reduced $\mathrm{CO}_{2}$ fluxes.

\section{METHODS}

\section{Experimental Design and Implementation of Treatments}

To test the effect of exogenous phenolic inhibitors on soil decomposition processes and Sphagnum papillosum productivity, a completely randomized design experiment with seven treatments was created using peat mesocosms within a greenhouse at Laval University, Quebec, Canada. The treatments tested were as follows: adding wood chips from three locally abundant tree species, Larch (Larix laricina), Spruce (Picea mariana), and Cedar (Thuja occidentalis), which are all common in Northern American peatlands, at the surface of the peat; mixing woodchips from the three same tree species within the top $10 \mathrm{~cm}$ of peat; and no amendment of the peat (baseline comparison). For all of the treatments, fresh $S$. papillosum fragments were added on top of the peat substrate. All treatments were repeated five times for a total of 35 experimental units (EUs).

Each EU was a mesocosm (plastic box) measuring $60 \times 40$ $\times 36 \mathrm{~cm}$ equipped with a perforated drain and pipe to allow the water table to be maintained at the desired level. Each EU was filled with $\sim 20 \mathrm{~cm}$ of bulk fibric peat (von Post: H3-4) collected from a vacuum extracted peatland. The peatland type was a raised bog from a region of lowland Quebec $\left(46^{\circ} 42^{\prime} \mathrm{N} 71^{\circ} 03^{\prime} \mathrm{W}\right)$ where ombrotrophic and peat-accumulating conditions arrived as early as 8,000 years ago, with a stable plant community comprising Sphagnum mosses, Chamaedaphne calyculata and Picea mariana (Lavoie et al., 2012). Mature trees from the three species were harvested in another natural peatland of the same ecoregion $\left(46^{\circ} 46^{\prime} \mathrm{N}, 71^{\circ} 00^{\prime} \mathrm{W}\right)$ and the trunks (without needles) were processed through a wood chipper to produce chips of $1-2 \mathrm{~cm}$ diameter. A layer of $\sim 2 \mathrm{~cm}$ of woodchips (corresponding to a dry weight of $500 \mathrm{~g}$ ) were either spread on top of the peat ("surface" treatments) or mixed with the top $10 \mathrm{~cm}$ of peat ("mixed" treatments). S. papillosum was hand collected in fragments of $\sim 10 \mathrm{~cm}$ in a natural peatland of the same ecoregion. Sphagnum fragments were spread on top of the amended peat in a ratio of 1:10-i.e., $1 \mathrm{~m}^{2}$ of Sphagnum collected in a natural peatland spread over $10 \mathrm{~m}^{2}$ of the mesocosms. Each mesocosm was watered twice every week with rainwater to maintain the water table at $5-10 \mathrm{~cm}$ below the peat surface. Greenhouses conditions were set at $22^{\circ} \mathrm{C}$ during the day and $18^{\circ} \mathrm{C}$ during the night with a constant $75 \%$ relative humidity and a photoperiod of $15 \mathrm{~h}$. The experiment took place over a 10 month period (July 2013-May 2014). 


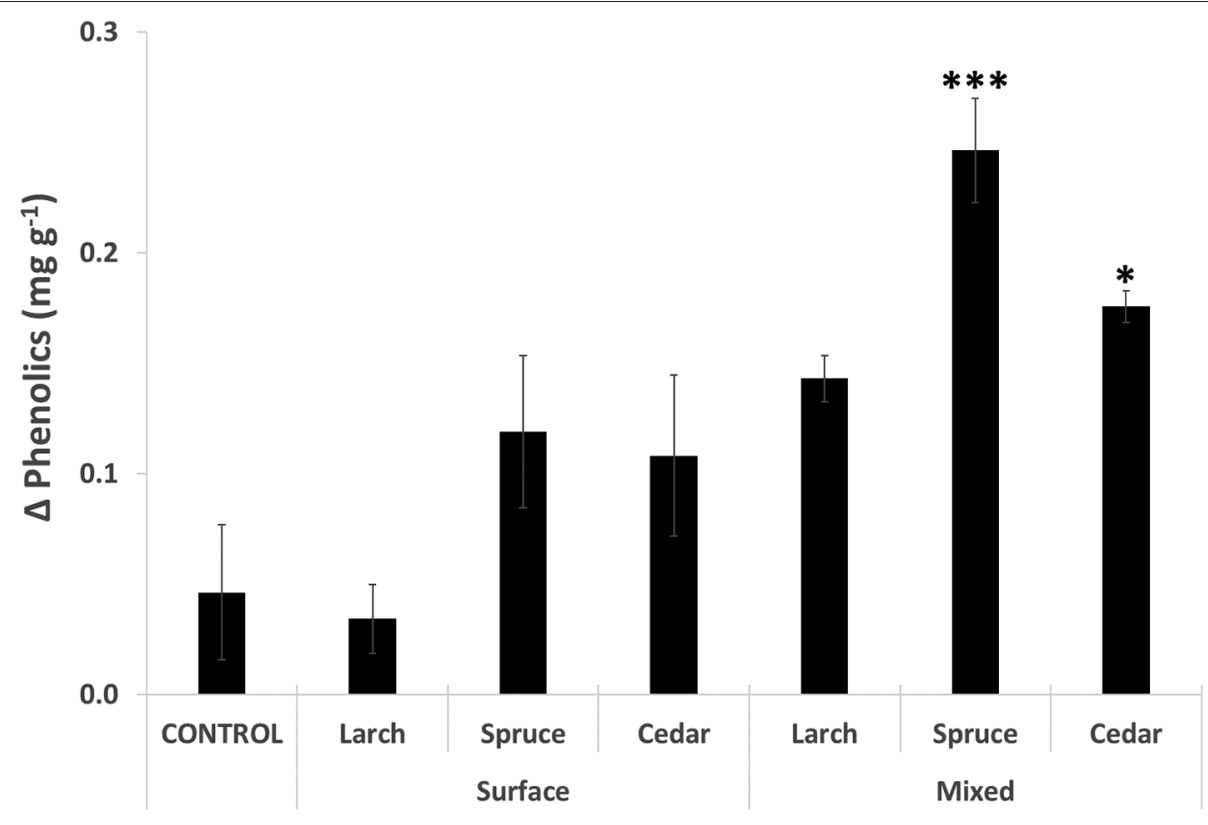

FIGURE 1 | Mean change in concentration of Phenolics over the period September 2013 to July $2014(n=5)$. Significance levels: ${ }^{\star} p<0.05$, ${ }^{\star \star \star} p<0.001$.

\section{Sampling}

Gas flux sampling was carried out using a static headspace technique. The opaque chambers $(19 \mathrm{~cm}$ height $\times 13-21 \mathrm{~cm}$ width) included a septum for sampling. Each chamber was placed on the peat/Sphagnum surface, pressed down gently to create a seal, and sampled after $1 \mathrm{~h}$ had elapsed, a time over which headspace $\mathrm{CO}_{2}$ accumulation remains linear (Freeman et al., 1993). A $20 \mathrm{ml}$ sample of gas was extracted and injected into $12 \mathrm{ml}$ Exetainer vials (Labco, Buckinghamshire, UK). Several samples of air from the greenhouse environment were also collected periodically during the flux analysis to provide the initial background concentration. Soil samples were collected from each EU before and at the end of the experimental period. This was achieved by extracting $\sim 200 \mathrm{~g}$ peat by hand (with plastic gloves) from a depth of $5-10 \mathrm{~cm}$ and placing the soil in a sandwich bag, which was then sealed and stored at $4^{\circ} \mathrm{C}$. All vials and soil samples were shipped to Bangor University, UK, for analysis.

S. papillosum cover was visually estimated at the end of the experiment. All Sphagnum carpets were then collected in each mesocosm, cleaned from any woodchip or peat residues, and weighed for biomass measurements.

\section{Laboratory Analyses}

The gas samples collected in the exetainer vials were analyzed using a Varian model 450 gas chromatograph (GC) instrument. The GC system is designed for the analysis of the three main greenhouse gases $\left(\mathrm{CH}_{4}, \mathrm{CO}_{2}, \mathrm{~N}_{2} \mathrm{O}\right)$, being equipped with a methanizer (temperature, $380^{\circ} \mathrm{C}$ ) and flame ionization detector (FID, $125^{\circ} \mathrm{C}$ ) for $\mathrm{CO}_{2}$ and $\mathrm{CH}_{4}$ and an electron capture detector $\left(\mathrm{ECD}, 300^{\circ} \mathrm{C}\right.$ ) for $\mathrm{N}_{2} \mathrm{O}$. Two milliliters of gas was extracted from the exetainer vials using a CombiPal autosampler (CTC
Analytics AG, Zwingen, Switzerland) equipped with a $5 \mathrm{ml}$ syringe and added to the column injector system $\left(100^{\circ} \mathrm{C}\right)$. Gases were separated on a $1.83 \mathrm{~m} \times 3.18 \mathrm{~mm}$ PoroPak QS 80/100 column $\left(40^{\circ} \mathrm{C}\right)$. Oxygen-free nitrogen, at a flowrate of $30 \mathrm{ml}$ $\min ^{-1}$, was used as the carrier gas. Gas fluxes were calculated by subtracting the mean values of the greenhouse atmosphere samples from each of the $1 \mathrm{~h}$ chamber values and expressing the flux values as $\mathrm{mg} \mathrm{m}^{-2} \mathrm{~h}^{-1}$.

Soil samples were analyzed for conductivity, the concentration of phenolic compounds, and the activity of $\beta$-D-glucosidase. Samples were prepared for the analysis of conductivity and phenolics using a water extraction method similar to that described by Chantigny (2003). The soil samples were homogenized, and $5 \mathrm{~g}$ was placed in a $50 \mathrm{ml}$ centrifuge tube (Fisher Scientific, Loughborough, UK) with $40 \mathrm{ml}$ of deionized water. The tubes were placed on a KS501 orbital shaker (Ika, Staufen, Germany) at a speed of $300 \mathrm{rpm}$ for $24 \mathrm{~h}$, after which conductivity was measured using a FiveGo conductivity meter (Mettler Toledo, Leicester, UK). Then, the samples were centrifuged at 5,000 rpm for $30 \mathrm{~min}$ on a Sorvall ST16R centrifuge (Thermo Fisher, Altricham, UK). The supernatant was filtered through $0.45 \mu \mathrm{M}$ syringe filters (Phenomenex, Macclesfield, UK) and analyzed for phenolics using a method adapted from Box (1983). One milliliter of the sample, $50 \mu \mathrm{l}$ of Folin-Ciocalteu phenol reagent (Sigma, Gillingham, UK), and $0.15 \mathrm{ml}$ of $\mathrm{Na}_{2} \mathrm{CO}_{3}$ $\left(200 \mathrm{~g} \mathrm{~L}^{-1}\right)$ were added to $1.5-\mathrm{ml}$ microcentrifuge tubes. The process was repeated for calibration standards $\left(0-30 \mathrm{mg} \mathrm{L}^{-1}\right)$ made from phenol (Sigma, Gillingham, UK). After $\sim 90 \mathrm{~min}$, $300 \mu \mathrm{l}$ of each sample and standard were transferred to wells of a clear 96-well microplate (Triple Red, Long Crendon, UK), and absorbance was measured at $750 \mathrm{~nm}$ on a SpectraMax M2e spectrophotometer (Molecular Devices, Wokingham, UK). 
Hydrolase enzyme ( $\beta$-glucosidase) activities were determined by following Dunn et al. (2014). All substrates were obtained from Glycosynth (Warrington, UK), prepared by dissolving in ethylene glycol monomethyl ether (Sigma) and deionized water, and stored at $4^{\circ} \mathrm{C}$ until required. A standard solution of $1,000 \mu \mathrm{M}$ 4-methylumbelliferone (MUF)-free acid was prepared using 4methylumbelliferone sodium salt (Sigma) and a dilution series prepared in 2- $\mathrm{ml}$ microcentrifuge tubes in the range of 0 $100 \mu \mathrm{M}$. Peat soil samples and substrates were placed in an incubator set to the mean temperature of the peat soil in the greenhouses $\left(\sim 20^{\circ} \mathrm{C}\right)$ the day before the assays were undertaken. The peat soil samples were homogenized by hand, and $1 \mathrm{~g}$ was placed in six separate stomacher bags (Seward, Worthing, UK), one for each of the five hydrolase enzyme substrates and the standard solution. To each stomacher bag, $7 \mathrm{ml}$ of the appropriate substrate or deionized water (standard solution) was added, and the bags were homogenized in a Stomacher 80 (Seward) for $30 \mathrm{~s}$. The bags were incubated at the mean greenhouse temperature for $60 \mathrm{~min}$ ( $45 \mathrm{~min}$ for phosphatase) and $1.5 \mathrm{ml}$ of solution centrifuged at $14,000 \mathrm{rpm}$. For the substrate solutions, $50 \mu \mathrm{l}$ of deionized water was pipetted into wells of a 96-well black microplate (Scientific Laboratory Supplies, Yorkshire, UK), followed by $250 \mu \mathrm{l}$ of supernatant from the substrate bags. For the standards, $50 \mu \mathrm{l}$ of each MUF-free standard solution was pipetted into the microplate followed by $250 \mu \mathrm{l}$ of supernatant from the peat/deionized water bag. The microplate was then analyzed by a SpectraMax M2e plate, using a fluorescence at $330 \mathrm{~nm}$ excitation and $450 \mathrm{~nm}$ emission. The instrument creates a calibration curve from the standards to calculate the enzyme concentration of the samples. From these values, the enzyme activities are calculated and expressed as $\mu \mathrm{mol} \mathrm{g}^{-1} \mathrm{~min}^{-1}$. Peat soil samples were also analyzed for dry weight and organic content by weighing samples in crucibles and following the standard methods detailed in Frogbrook et al. (2009).

\section{Statistical Analyses}

First, for the soil parameters, the differential change from 2 to 10 months incubation, thus a period of 8 months, was calculated. The subtraction was made from month 2 , rather than month 0 , to account for a period of stabilization of the mesocosms following their creation.

The effect of the exogenous phenolic inhibitors on the measured above- and below-ground parameters were determined using the Kruskal-Wallis test for a randomized complete block design and non-normally distributed data. For the soil parameters (conductivity, phenolics, hydrolase enzyme activities, and greenhouse gas fluxes), the analysis was performed in $\mathrm{R}$ v3.3.1 and used pairwise comparisons using Dunn's test where significant treatment effects were found. Pearson correlation was used to test for significant relationships between parameters. The effect of the exogenous phenolic inhibitors on S. papillosum cover and biomass was analyzed using the MIXED procedure of SAS (SAS Statistical System Software, v. 9.2, SAS Institute Inc., Cary, NC, USA). Following the ANOVAs, protected Fisher's least significant differences (LSDs) were run when a significant difference between treatments was found. Data met the homogeneity and normality assumptions.

\section{RESULTS}

\section{Phenolic Content}

Over the 10 month incubation period, the concentration of phenolics increased for all 35 EUs, and all but one treatment (Larch, surface) had a higher mean concentration compared to the control (Figure 1). There was a significant treatment effect on phenolics $(H=21.472, p<0.01)$, with post hoc analysis revealing significantly greater increases in phenolics for the treatments with mixed additions of Spruce $(5 \times$ greater than control) and Cedar $(3.5 \times$ greater than control).

\section{Extracellular Hydrolases}

In terms of extracellular enzymic activity, the wood chip addition treatments suppressed the activity of the indicator hydrolase enzyme $\beta$-glucosidase. The mean activity of the enzyme was lower for all treatments after the 10 month incubation period, with a greater reduction in activity being observed for all six wood chip addition treatments compared to the control (Figure 2). There was a significant overall treatment effect $(H=18.488, p$ $<0.01$ ), with post hoc analysis showing significant reductions in activity for all three mixed wood chip treatments compared to the control. Inversely to the greatest increase in phenolic concentration caused by the Spruce, mixed treatment, this same treatment had the greatest suppression of $\beta$-glucosidase activity, almost $20 \times$ lower compared to the control. The Larch and Cedar mixed wood chip addition treatments reduced the $\beta$-glucosidase activity by $5-6 \times$ compared to the control.

\section{$\mathrm{CO}_{2}$}

The $\mathrm{CO}_{2}$ flux data were analyzed in the same way as the phenolic and enzyme data, by calculating the difference from month 2 to 10 , to allow time for the soil to stabilize following the initial treatment. The mean $\mathrm{CO}_{2}$ flux increased slightly in the control treatment with no wood chip additions, but decreased in all of the treatments with wood chips added, with a significant treatment effect (Figure 3; $H=14.26 ; p<0.05$ ). Post hoc analysis demonstrated that it was the surface and mixed additions of Larch, and surface only addition of Spruce wood chips, that led to statistically significant reductions in the $\mathrm{CO}_{2}$ flux compared to the control. The initial fluxes of $\mathrm{CO}_{2}$ showed large spikes and a high degree of variability between the treatments during the initial posttreatment stabilization. This coincided with a period of instrument concerns but may have been a disturbance effect or resulted from an initial flush of labile carbon from the wood chips causing a temporary stimulation of decomposition. There would be some value in further studies of this initial phase with the aim of producing a carbon budget for the entire experiment. $\mathrm{CH}_{4}$ and $\mathrm{N}_{2} \mathrm{O}$ fluxes were also measured, but the variability between and within each treatment was consistently high throughout the experiment, so these data have not been analyzed further.

A significant negative relationship was observed between the mean change in both phenolics concentration and $\beta$-glucosidase activity (Figure 4; $r=-0.51, p<0.01$ ).

\section{Vegetation}

No significant effect of phenolic enrichment was recorded on Sphagnum cover nor biomass. Sphagnum productivity was thus 


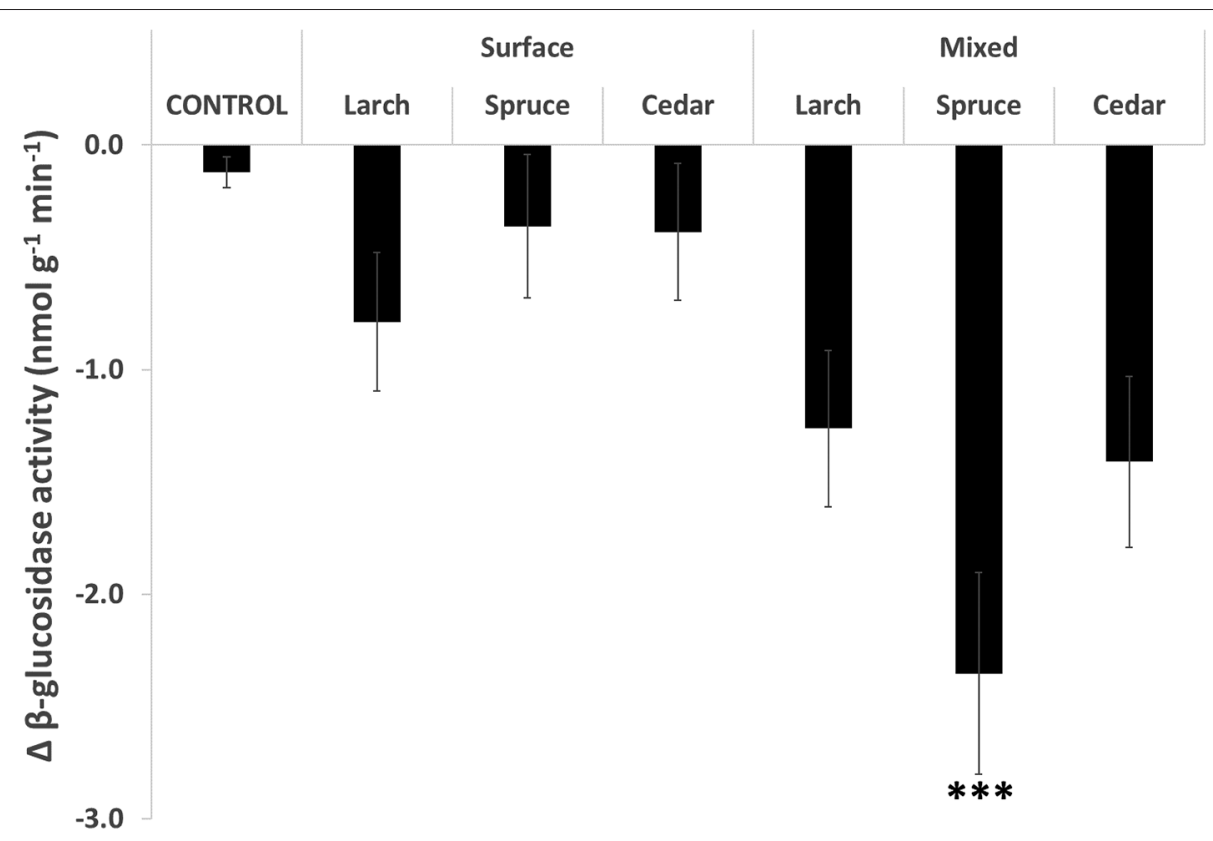

FIGURE 2 | Mean change in activity of $\beta$-glucosidase over the period September 2013 to July $2014(n=5)$. Significance levels: ${ }^{\star \star \star} p<0.001$.

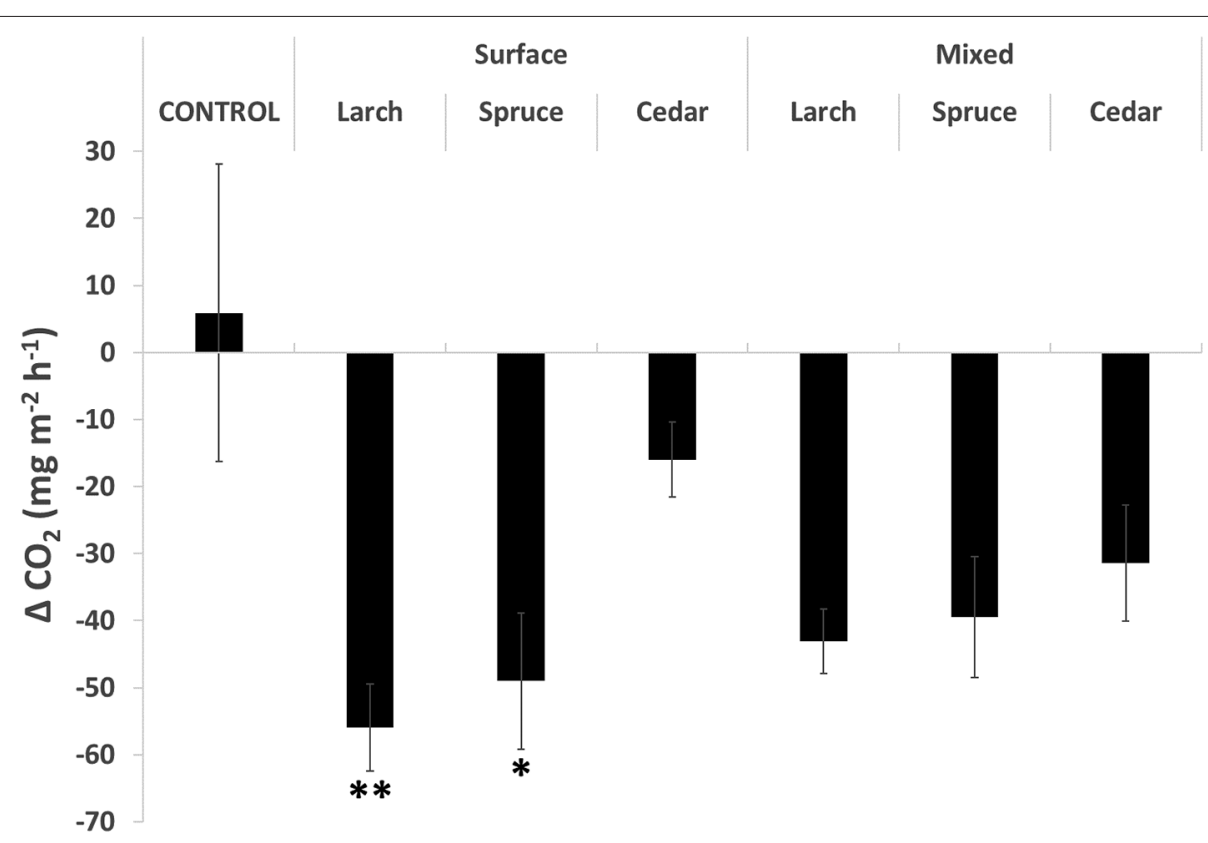

FIGURE 3 | Mean change in $\mathrm{CO}_{2}$ flux over the period September 2013 to July $2014(n=5)$. Significance levels: ${ }^{*} p<0.05$, ${ }^{\star *} p<0.01$.

similar between the control treatment and the treatments with added woodchips.

\section{DISCUSSION}

This mesocosm experiment has demonstrated that it is possible to increase the concentration of phenolic compounds and consequently reduce soil enzyme activities and $\mathrm{CO}_{2}$ emissions during peatland restoration through the addition of exogenous phenolic compounds in the form of wood chips. The work therefore supports proposals in previous studies that phenolic supplements can suppress microbial metabolism and therefore reduce $\mathrm{CO}_{2}$ fluxes to the atmosphere (Freeman et al., 2012; Fenner and Freeman, 2020), and other studies proposing 


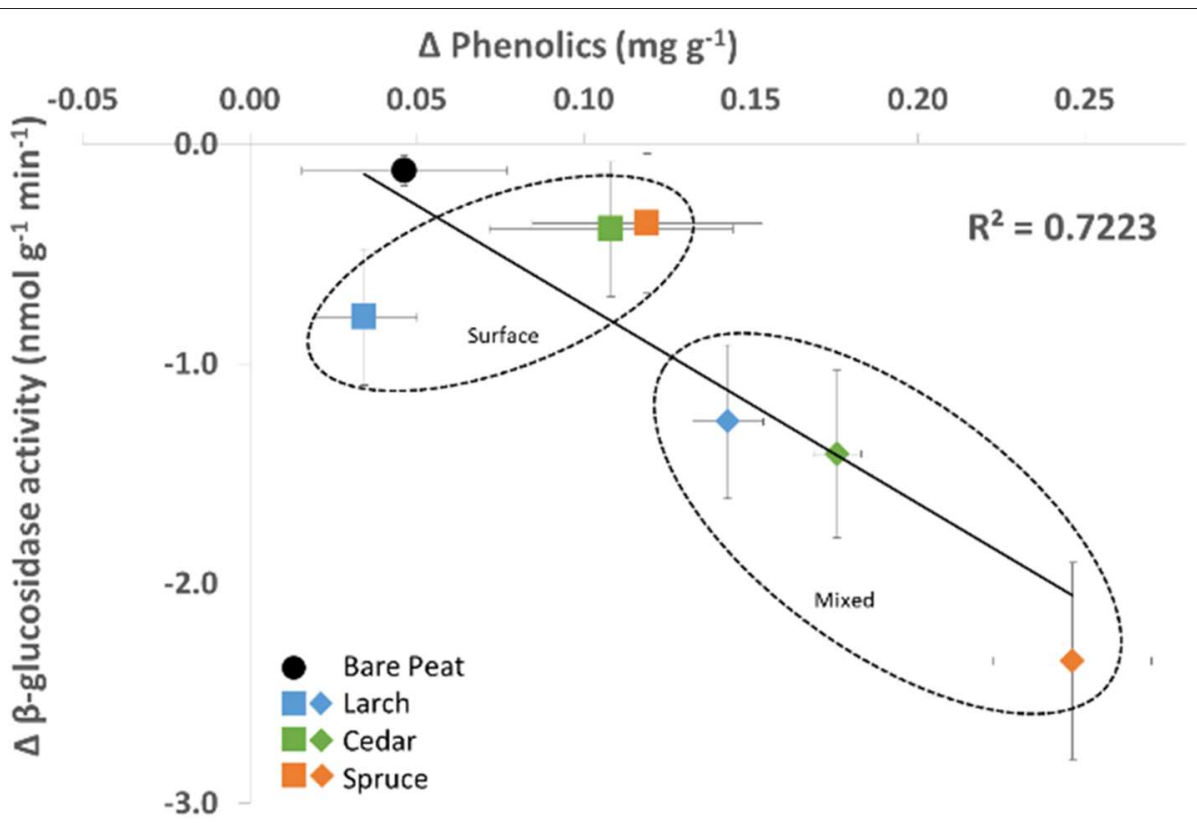

FIGURE 4 | Relationship between mean change in concentration of Phenolics and mean change in $\beta$-glucosidase activity over the period September 2013 to July $2014(n=5)$.

phenolic content in peat ecosystems can be enhanced by either increased expression of phenolic inhibitors from peatland plants or by enhancement of the enzyme latch by physicochemical modification (Min et al., 2015). However, we acknowledge that the addition of woody materials may initially lead to a short-term increase in $\mathrm{CO}_{2}$ emissions as any labile materials within that supplement decompose and that there is a risk of temporarily priming decomposition. Clearly, further research would be required (a) to assess this potential risk, (b) to identify sources of wood with minimal labile material content, and (c) to seek further treatments using natural inhibitors that could suppress the metabolism of any labile materials added with the supplements.

The process of mixing the wood chips into the peat profile was found to be particularly effective at increasing phenolics concentration (rather than direct surface application), probably because it increases the surface area of wood chips in contact with soil and causes the dissolved phenolic release from the wood chips to be more widely distributed throughout the soil profile. It should be noted that in terms of Sphagnum growth, the presence of woodchips in the soil profile could potentially reduce the availability of water in the capitulum of the plant by reducing the capillary rise of the water to the surface of the peat. The potential detrimental effect of woodchip amendments on upward water movement might be expected to be more important for the surface only added treatment than for the mixed within the surface peat treatment. However, no detrimental effect on Sphagnum growth was observed for any of the addition treatments. In this experiment, the presence of woodchips (of any tree species, either at the surface or mixed with the peat) did not impede Sphagnum growth, probably because the water table was maintained relatively high $(5-10 \mathrm{~cm}$ below the surface) and watered twice a week from above simulating regular rain events.

Of the three wood materials used as sources of phenolics, Spruce had the greatest impact in terms of elevating phenolics and suppressing $\beta$-glucosidase in the "mixed" treatments only, but Larch had a greater impact more generally in reducing the $\mathrm{CO}_{2}$ emissions, being effective for both the surface applied and mixed wood chip treatments. Previous laboratory experimental work demonstrated that, on its own, Cedar released $\sim 3.5$ times more phenolics into water than the other two wood types (data not shown); however, in this experiment, it did not significantly decrease $\beta$-glucosidase activity or $\mathrm{CO}_{2}$ emissions and did not increase the phenolics concentration of the peat soil as much as spruce. Clearly, the source of applied phenolics can have a major influence in the success of the approach, and other sources of phenolics should be evaluated for effectiveness. For example, Yoo and Kang (2012) reported that the addition of biochar with high phenolics content could represent a further approach to stabilize soil organic matter (SOM) in terrestrial ecosystems by inhibiting enzyme activities.

\section{CONCLUSION}

Our results show that the addition of supplementary phenolic compounds, especially when mixed into the peat soil, is an effective method of enhancing carbon sequestration during peatland restoration, and the enzymic latch might be the reason behind that carbon sequestration. Further research is required including testing the effect of phenolic addition on a larger scale and whether alternative phenolic compounds result in 
more inhibition when added to the peat surface or when mixed into the substrate. Longer-term monitoring would also be beneficial, and alternative tree species investigated as a source of wood chips.

\section{DATA AVAILABILITY STATEMENT}

All datasets generated for this study are included in the article/supplementary material.

\section{AUTHOR CONTRIBUTIONS}

LR and CF conceived the project. CD and LR formulated the experimental design and logistics plan. SH collected field samples. AA conducted the laboratory analysis. AA and TJ

\section{REFERENCES}

Box, J. D. (1983). Investigation of the Folin-Ciocalteau phenol reagent for the determination of polyphenolic substances in natural waters. Water Res. 17, 511-525. doi: 10.1016/0043-1354(83)9 0111-2

Chantigny, M. H. (2003). Dissolved and water-extractable organic matter in soils: a review on the influence of land use and management practices. Geoderma 113, 357-380. doi: 10.1016/S0016-7061(02)0 0370-1

Dunn, C., Jones, T. G., Girard, A., and Freeman, C. (2014). Methodologies for extracellular enzyme assays from wetland soils. Wetlands 34, 9-17. doi: 10.1007/s13157-013-0475-0

Fenner, N., and Freeman, C. (2020). Woody litter protects carbon stocks during drought. Nat. Clim. Chang. 10, 363-369. doi: 10.1038/s41558-0200727-y

Freeman, C., Fenner, N., and Shirsat, A. H. (2012). Peatland geoengineering: an alternative approach to terrestrial carbon sequestration. Philos. Trans. R. Soc A 370, 4404-4421. doi: 10.1098/rsta.2012.0105

Freeman, C., Hawkins, J., Lock, M. A., and Reynolds, B. (1993). “A laboratory perfusion system for the study of biogeochemical responses of wetlands to climatic change." in Wetlands and Ecotones: Studies on Land-Water Interactions, eds B. Gopal, A. Hillbricht-Ilkowska, and R. G. Wetzel (New Delhi: National Institute of Ecology), 75-84.

Freeman, C., Lock, M. A., Marxsen, J., and Jones, S. E. (1990). Inhibitory effects of high molecular weight dissolved organic matter upon metabolic processes in biofilms from contrasted rivers and streams. Freshw. Biol. 24, 159-166. doi: 10.1111/j.1365-2427.1990.tb00315.x

Freeman, C., Ostle, N., and Kang, H. (2001). An enzymic 'latch' on a global carbon store - a shortage of oxygen locks up carbon in peatlands by restraining a single enzyme. Nature 409, 149-149. doi: 10.1038/350 51650

Frogbrook, Z. L., Bell, J., Bradley, R. I., Evans, C., Lark, R. M., Reynolds, B., et al. (2009). Quantifying terrestrial carbon stocks: examining the spatial variation in two upland areas in the UK and a comparison to mapped estimates of soil carbon. Soil Use Manag. 25, 320-332. doi: 10.1111/j.1475-2743.2009.0 0232.x

Haslam, E. (1989). Plant Polyphenols: Vegetable Tannins Revisited. Cambridge: Cambridge University Press.

Horner, J. D., Gosz, J. R., and Cates, R. G. (1988). The role of carbon-based plant secondary metabolites in decomposition in terrestrial ecosystems. Am. Nat. 132, 869-883. doi: 10.1086/284894

Joosten, H. (2016). "Peatlands across the globe," in Peatland Restoration and Ecosystem Services: Science, Policy and Practice, eds A. Bonn, T. Allott, M. Evans, H. Joosten, and R. Stoneman (Cambridge: Cambridge University Press), 19-43.

Joosten, H., Sirin, A., Couwenberg, J., Laine, J., and Smith, P. (2016). The role of peatlands in climate regulation. in Peatland Restoration and Ecosystem Services: analyzed the data and wrote the first draft of the manuscript. All authors contributed to subsequent revisions and refinement of interpretation.

\section{FUNDING}

Financial support was provided by the Natural Sciences and Engineering Research Council of Canada (grant no. IRCPJ 282989-2012), the Canadian Sphagnum Peat Moss Association and its members.

\section{ACKNOWLEDGMENTS}

We thank Noémie D'Amour and Christiane Dupont for the greenhouse gas and vegetation sampling.

Science, Policy and Practice, eds A. Bonn, T. Allott, M. Evans, H. Joosten, and R. Stoneman (Cambridge: Cambridge University Press), 63-76.

Laine, J., and Minkkinen, K. (1996). Effect of forest drainage on the carbon balance of a mire: a case study. Scand. J. For. Res. 11, 307-312. doi: 10.1080/02827589609382940

Lavoie, C., Allard, M., and Duhamel, D. (2012). Deglaciation landforms and C-14 chronology of the Lac Guillaume-Delisle area, eastern Hudson Bay: a report on field evidence. Geomorphology s159-160, 142-155. doi: 10.1016/j.geomorph.2012.03.015

Meier, C. L., Suding, K. N., and Bowman, W. D. (2008). Carbon flux from plants to soil: roots are a below-ground source of phenolic secondary compounds in an alpine ecosystem. J. Ecol. 96, 421-430. doi: 10.1111/j.1365-2745.2008.0 1356.x

Min, K., Freeman, C., Kang, H., and Choi, S.-U. (2015). The regulation by phenolic compounds of soil organic matter dynamics under a changing environment. BioMed Res. Int. 2015:825098. doi: 10.1155/2015/8 25098

Northup, R. R., Dahlgren, R. A., and McColl, J. G. (1998). Polyphenols as regulators of plant-litter-soil interactions in northern California's pygmy forest: a positive feedback? Biogeochemistry 42, 189-220. doi: 10.1007/978-94-017-2 691-7_10

Painter, T. J. (1983). Residues of D-lyxo-5-hexosulopyranuronic acid in Sphagnum holocellulose, and their role in cross-linking. Carbohydr. Res. 124, C18-C21. doi: 10.1016/0008-6215(83)88373-6

Paul, E. A., and Clark, F. E. (1989). Soil Microbiology and Biochemistry. San Diego, CA: Academic Press Inc.

Ramchunder, S. J., Brown, L. E., and Holden, J. (2009). Environmental effects of drainage, drain-blocking and prescribed vegetation burning in UK upland peatlands. Prog. Phys. Geogr. 33, 49-79. doi: 10.1177/03091333091 05245

Rasmussen, S., Wolff, C., and Rudolph, H. (1995). Compartmentalization of phenolic constituents in Sphagnum. Phytochemistry 38, 35-39. doi: 10.1016/0031-9422(94)00650-I

Tejirian, A., and $\mathrm{Xu}, \mathrm{F}$. (2011). Inhibition of enzymatic cellulolysis by phenolic compounds. Enzyme Microb. Technol. 48, 239-247. doi: 10.1016/j.enzmictec.2010.11.004

Toberman, H., Freeman, C., Evans, C., Fenner, N., and Artz, R. R. E. (2008). Summer drought decreases soil fungal diversity and associated phenol oxidase activity in upland Calluna heathland soil. FEMS Microbiol. Ecol. 66, 426-436 doi: 10.1111/j.1574-6941.2008.0 0560.x

Verhoeven, J. T. A., and Toth, E. (1995). Decomposition of Carex and Sphagnum litter in fens: effect of litter quality and inhibition by living tissue homogenates. Soil Biol. Biochem. 27, 271-275. doi: 10.1016/0038-0717(94)0 0183-2

Waddington, J. M., Warner, K. D., and Kennedy, G. W. (2002). Cutover peatlands: a persistent source of atmospheric $\mathrm{CO}_{2}$. Global Biogeochem. Cycles 16:1002. doi: 10.1029/2001GB001398 
Wetzel, R. G. (1992). Gradient-dominated ecosystems: sources and regulatory functions of dissolved organic matter in freshwater ecosystems. Hydrobiologia 229, 181-198. doi: 10.1007/BF000 07000

Xu, J., Morris, P. J., Liu, J., and Holden, J. (2018). PEATMAP: refining estimates of global peatland distribution based on a meta-analysis. Catena 160, 134-140. doi: 10.1016/j.catena.2017.09.010

Yoo, G., and Kang, H. (2012). Effects of biochar addition on greenhouse gas emissions and microbial responses in a short-term laboratory experiment. J. Environ. Qual. 41, 1193-1202. doi: 10.2134/jeq201 1.0157
Conflict of Interest: The authors declare that the research was conducted in the absence of any commercial or financial relationships that could be construed as a potential conflict of interest.

Copyright (C) 2020 Alshehri, Dunn, Freeman, Hugron, Jones and Rochefort. This is an open-access article distributed under the terms of the Creative Commons Attribution License (CC BY). The use, distribution or reproduction in other forums is permitted, provided the original author(s) and the copyright owner(s) are credited and that the original publication in this journal is cited, in accordance with accepted academic practice. No use, distribution or reproduction is permitted which does not comply with these terms. 